\title{
Systematic analysis on the obtaining of fibrinolytic fungi enzymes
}

\author{
Análise sistemática sobre a obtenção de enzimas fibrinolíticas a partir de fungos \\ Análisis sistemático sobre la obtención de enzimas fibrinolíticas a partir de hongos
}

\author{
Kethylen Barbara Barbosa Cardoso \\ ORCID: https://orcid.org/0000-0003-0317-0307 \\ Universidade Federal de Pernambuco, Brasil \\ E-mail: kethybarbara@gmail.com \\ Maria Clara Nascimento \\ ORCID: https://orcid.org/0000-0003-2388-2133 \\ Universidade Federal Rural de Pernambuco, Brasil \\ E-mail: mclaranaascimento@hotmail.com \\ Anna Carolina Batista \\ ORCID: https://orcid.org/0000-0003-0574-9339 \\ Universidade Federal Rural de Pernambuco, Brasil \\ E-mail: annacarolinabio23@gmail.com \\ Vagne de Melo Oliveira \\ ORCID: https://orcid.org/0000-0003-0841-1974 \\ Universidade Federal do Acre, Brasil \\ E-mail: vagne_melo@hotmail.com \\ Thiago Pajeú Nascimento \\ ORCID: https://orcid.org/0000-0003-3480-6734 \\ Universidade Federal do Piauí, Brasil \\ E-mail: thiago_pajeu@ hotmail.com \\ Juanize Matias da Silva Batista \\ ORCID: https://orcid.org/0000-0001-7654-2533 \\ Universidade Federal Rural de Pernambuco, Brasil \\ E-mail: juanizematias@yahoo.com.br \\ Romero Marcos Pedrosa Brandão Costa \\ ORCID: https://orcid.org/0000-0001-7045-2975 \\ Universidade de Pernambuco, Brasil \\ E-mail: romero_brandao@yahoo.com.br \\ Lorenzo Pastrana \\ ORCID: https://orcid.org/0000-0002-6637-3462 \\ International Iberian Nanotechnology Laboratory, Brasil \\ E-mail: lorenzo.pastrana@inl.int \\ Ana Lúcia Figueiredo Porto \\ ORCID: https://orcid.org/0000-0001-5561-5158 \\ Universidade Federal Rural de Pernambuco, Brasil \\ E-mail: analuporto@yahoo.com.br
}

\begin{abstract}
Fibrinolytic proteases operate directly on fibrin clot and are able to maintain blood flow. Fungi show up as viable sources for obtaining this enzyme. The purpose of this systematic review is to is to unveil all the information concerning production, purification and characterization of fibrinolytic proteases by fungi. The search was conducted in ScienceDirect, PubMed and Scopus databases, using as keywords "(Fibrinolytic enzyme) OR (Fibrinolytic protease) AND (Fungal or Fungus or Fungi)". Delimiting period of 10 years (2011-2021). The results obtained were filtered by selection criteria, and review articles or articles outside the scope of this work were excluded. The articles were evaluated and scored (0-10) according to pre-established criteria. None of the studies obtained the score 10, however the study with the highest score (9) presented relevant data in all criteria analyzed, obtaining fibrinolytic enzyme from Xylaria curta. Among the 21 selected articles, 12 different genera appear and Submerged Fermentation and purification of Serino-proteases were more described. This work also observed a greater representation of purification and characterization steps, indicating the need for attention to cultivation process and enzymatic application. It is clear that the production of these enzymes by fungi is pertinent towards the high recovery observed even after purification and its tendency for pharmaceutical application.
\end{abstract}

Keywords: Protease; Thrombolytic; Mushroom; Filamentous fungi; Fermentation; Purification.

\section{Resumo}

Proteases fibrinolíticas destacam-se por atuarem diretamente no coágulo de fibrina e conseguir manter o fluxo sanguíneo. Fungos despontam na literatura como fontes viáveis na obtenção dessa enzima. Desta forma, o propósito 
desta revisão sistemática é analisar as informações disponiveis a respeito da produção, purificação e caracterização de proteases fibrinolíticas por fungos. A pesquisa foi conduzida nas bases ScienceDirect, PubMed e Scopus, utilizando como palavras-chave " (Fibrinolytic enzyme) OR (Fibrinolytic protease) AND (Fungal or Fungus or Fungi)". Delimitando período de 10 anos (2011-2021). Os resultados obtidos foram filtrados por critérios de seleção, sendo excluídos artigos de revisão e artigos fora do escopo deste trabalho. Os artigos foram avaliados e pontuados (0-10) segundo critérios pré-estabelecidos. Nenhum dos trabalhos obteve pontuação máxima, entretanto o trabalho com maior pontuação (9) apresentou dados relevantes em todos os critérios analisados, obtendo enzima fibrinolítica de Xylaria curta. Dentre os 21 artigos selecionados foram descritos 12 gêneros diferentes e o uso de Fermentação Submersa e a purificação de Serino proteases foram mais descritos. Este trabalho também observou maior representação de etapas de purificação e caracterização, indicando a necessidade de atenção ao cultivo e aplicação enzimática. Está claro que a produção destas enzimas por fungos é pertinente tendo em vista a alta recuperação observada mesmo após purificação e sua tendência a aplicação farmacêutica.

Palavras-chave: Protease; Trombolítico; Cogumelo; Fungos filamentosos; Fermentação; Purificação.

\section{Resumen}

Las proteasas fibrinolíticas destacan por actuar directamente sobre el coágulo de fibrina y mantener el flujo sanguíneo. Los hongos aparecen en la literatura como fuentes viables para la obtención de esta enzima. Así, el propósito de esta revisión sistemática es analizar la información disponible sobre la producción, purificación y caracterización de proteasas fibrinolíticas por hongos. La búsqueda se realizó en las bases de datos ScienceDirect, PubMed y Scopus, utilizando como palabras clave " (Enzima fibrinolítica) OR (Proteasa fibrinolítica) AND (Fungal or Fungus or Fungi) ". Plazo delimitador de 10 años (2011-2021). Los resultados obtenidos fueron filtrados por criterios de selección, excluyendo artículos de revisión y artículos fuera del campo de aplicación de este trabajo. Los artículos fueron evaluados y puntuados (0-10) según criterios preestablecidos. Ninguno de los estudios obtuvo la mayor puntuación, sin embargo el estudio con mayor puntuación (9) presentó datos relevantes en todos los criterios analizados, obteniendo la enzima fibrinolítica de Xylaria curta. Entre los 21 artículos seleccionados, se describieron 12 géneros diferentes y se describió más el uso de Fermentación Sumergida y la purificación de Serino proteasas. Este trabajo también observó una mayor representación de los pasos de purificación y caracterización, lo que indica la necesidad de atención al cultivo y la aplicación enzimática. Es evidente que la producción de estas enzimas por hongos es pertinente en vista de la alta recuperación observada incluso después de la purificación y su tendencia a la aplicación farmacéutica.

Palabras clave: Proteasa; Trombolítico; Champiñón; Hongos filamentosos; Fermentación; Purificación.

\section{Introduction}

The formation of fibrin clots is an important process in the regulation of the hemostatic system as well as its dissolution through fibrinolysis. However, the imbalance caused by some disorders can result in failure in the process of dissolving these clots. The consequent interruption of blood flow can cause serious problems for the affected individual, such as thrombosis, myocardial infarction, stroke, among other diseases linked to the cardiovascular system. Thus, it is extremely important to develop fibrinolytic agents that can be used in this sense, that are functional and have a low production cost (Andrade et al., 2018; Lins et al., 2019). Among the recommended treatments for coping with thrombosis, anticoagulants are the best known. However, in addition to the high production cost, these drugs have dangerous side effects, which can cause adverse bleeding, gastrointestinal discomfort, liver damage, and others. A second alternative is the use of fibrinolytic (or thrombolytic) agents, such as urokinase, streptokinase and tissue plasminogen activator (t-PA). However, these also present problems related to adverse bleeding, in addition to having a short half-life and restricted sources, making it difficult to obtain and apply (Ali et al., 2020).

Proteases with fibrinolytic action stand out for their successful dissolution of clots and maintenance of blood flow. Fibrinolytic enzymes can be classified into serine protease, metalloprotease and serine metalloprotease (Ali et al., 2020; Bin et $a l ., 2009)$. Those belonging to the first group are able to act both directly and indirectly in fibrin degradation, that is, by cleavage or by activation of plasmin. Metalloprotease with fibrinolytic action are rare, but act in the presence of bivalent metallic ions such as $\mathrm{Zn}^{2+}, \mathrm{Mg}^{2+}$, and $\mathrm{Ca}^{2+}$. The serine metalloproteases in turn combine properties of both previously described (Ali et al., 2020; Bin et al., 2009). 
These enzymes can be obtained from different sources, being widely produced by different microorganisms (Raju et al., 2013). Furthermore, when obtained from the fermentation of fungi, the production cost is relatively lower and benefits itself from advantages such as its cosmopolitan distribution and ease of large-scale production (Chen et al., 2016).

Given its indispensability, the need to search for new fibrinolytic enzymes is highlighted. The development of new production methods, sources, fermentation conditions, extraction, and purification methodologies has been a strong trend in research in the area, since these enzymes have a wide application spectrum with high biotechnological potential. In this context, this systematic review will discuss the criteria for obtaining, characterizing and purifying fibrinolytic enzymes produced by fungi.

\section{Methodology}

This research was carried out using the systematic review model, based on the following process: Searches of research articles were performed in popular databases, these being ScienceDirect (https/www.sciencedirect.com), PubMed (https://pubmed.ncbi.nlm.nih.gov/) and Scopus (https/www.scopus.com) using as keywords "(Fibrinolytic enzyme) OR (Fibrinolytic protease) AND (Fungal or Fungus or Fungi)". For selection of articles, inclusion and exclusion criteria were established based on those proposed by Wanderley (2017), adapted. The selection was made on a two-step analysis, the first step being performed superficially (or initially) taking into account only the title and abstract and the second step (or final step) in more detail analyzing the entire body of the text. Authorial research articles published in the last 10 years (2011-2021) that dealt with the production, purification and/or characterization of fibrinolytic enzymes produced by fungi in general were included in the analysis. Review articles and articles that did not use fungus in the methodology, or did not discriminate against the fungus used, were excluded. Items of the methodology such as how to obtain the enzyme, culture conditions, enzymatic activity, types of analysis and quantification of results were not taken into account for inclusion/exclusion criteria.

From the selected studies, evaluations were made regarding the methodologies for obtaining the enzyme, enzymatic activity, characterization, purification and application. A score was assigned to each of these criteria using the system proposed by Greenhalgh (1997), where each criterion can score 2 when the methodology is adequately present, or complete; can score 1 when the methodology is present but inadequately or incompletely; or it can score 0 when the methodology is not present. A summary of the evaluation and scoring criteria can be seen in Table 1.

Table 1. Evaluation criteria and referent score used to analyze the selected articles.

\begin{tabular}{|c|c|c|c|}
\hline \multirow[t]{2}{*}{ Rating criteria } & \multicolumn{3}{|c|}{ Score } \\
\hline & $\mathbf{0}$ & 1 & 2 \\
\hline (A) Production & Absent & Without variables & With variables \\
\hline (B) Characterization & Absent & Partial & Total \\
\hline $\begin{array}{l}\text { (C) Fibrinolytic } \\
\text { Activity }\end{array}$ & Absent & Fibrin plate & Spectrophotometry \\
\hline (D) Purification & Absent & Partical & Total \\
\hline (E) Aplications & Absent & - & Present \\
\hline
\end{tabular}

Source: Authors (2022). 


\section{Results and discussion}

\subsection{Selection of articles}

In phase 1 (article selection), 426 citations were identified in the electronic databases. After the initial evaluation, duplicate articles were removed and with objectives different from those addressed in this work, leaving 34 publications. The comprehensive evaluation of the full articles was completed and 13 articles were excluded, with 21 citations remaining. A flowchart detailing the process of identifying, including, and excluding studies is shown in Figure 1.

Figure 1. Flowchart of the article selection process using inclusion and exclusion criteria.

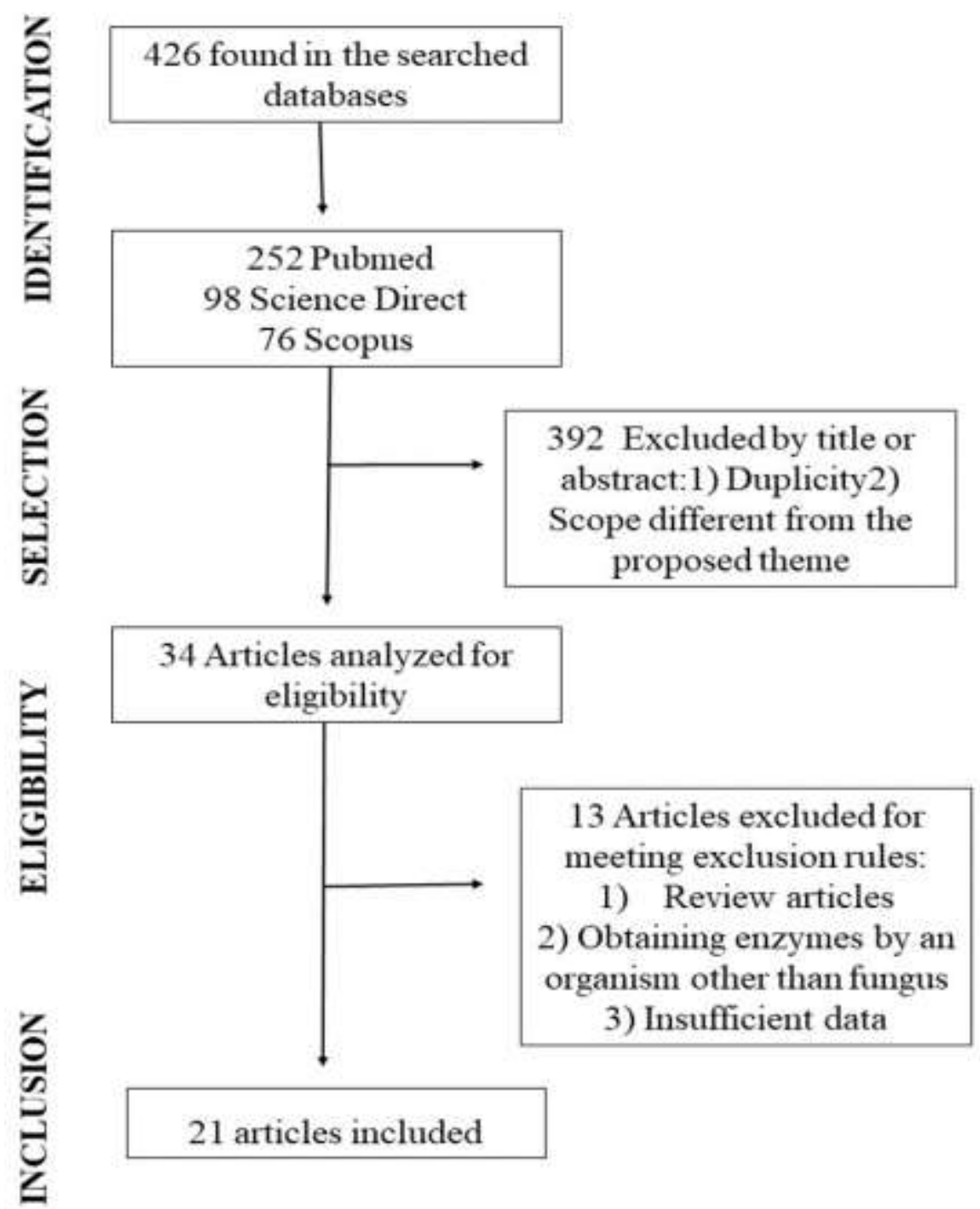

Source: Authors (2022).

\subsection{Characteristics of articles and punctuation}

A summary of the main characteristics of the included studies is provided in Table 2. As described in the methodology, the articles were selected in the period 2011-2021, among those selected 11 were published in the last five years, only one article was published in the year 2021 and one in 2020. All studies evaluated the acquisition of fibrinolytic enzymes by fungi, as well as some level of purification and characterization of the enzyme. In contrast, not all articles reported in detail the fermentation conditions, especially articles that used mushrooms. 
Table 2. Main characteristics of selected articles.

\begin{tabular}{|c|c|c|c|c|c|c|c|c|c|c|}
\hline \multirow[t]{2}{*}{ FUNGUS } & \multicolumn{4}{|c|}{ OBTAINING THE ENZYME } & \multicolumn{2}{|c|}{ FIBRINOLYTIC ACTIVITY } & \multicolumn{3}{|c|}{ CHARACTERIZATION } & \multirow[t]{2}{*}{ REFERENCE } \\
\hline & Fermentation & Temp. & Substrate & Time (days) & Method & $\begin{array}{c}\text { Specific Activity } \\
\text { (U/mg) }\end{array}$ & pH and temp. & Inhibitors & Mass & \\
\hline $\begin{array}{l}\text { Paecilomyces } \\
\text { tenuipes }\end{array}$ & - & - & - & - & Fibrin plate & 2,6 & $\mathrm{pH} 5,35^{\circ} \mathrm{C}$ & PMSF & $14 \mathrm{kDa}$ & (Kim et al., 2011) \\
\hline $\begin{array}{l}\text { Cordyceps } \\
\text { militaris }\end{array}$ & - & - & - & - & Fibrin plate & 5,8 & $\mathrm{pH} 7,40^{\circ} \mathrm{C}$ & PMSF & $34 \mathrm{kDa}$ & (Choi et al., 2011) \\
\hline $\begin{array}{l}\text { Ganoderma } \\
\text { lucidum }\end{array}$ & $\mathrm{SmF}$ & $30^{\circ} \mathrm{C}$ & MCDBF & 15 & Fibrin zymography & 350 & - & - & - & (Kumaran et al., 2011) \\
\hline Aspergillus oryzae & $\mathrm{SmF}$ & $28^{\circ} \mathrm{C}$ & Liquified rice & 7 & Fibrin plate & 5,5 & $\mathrm{PH} 6,50^{\circ} \mathrm{C}$ & PMSF & $30 \mathrm{kDa}$ & (Shirasaka et al., 2012) \\
\hline $\begin{array}{l}\text { Hericium } \\
\text { erinaceum }\end{array}$ & - & - & - & - & Spectrophotometry & 0,41 & $\mathrm{pH} 7,30^{\circ} \mathrm{C}$ & EDTA, EGTA & $51 \mathrm{kDa}$ & (Choi et al., 2013) \\
\hline $\begin{array}{l}\text { Auricularia } \\
\text { polytricha }\end{array}$ & - & - & - & - & Fibrin plate & 10,83 & PH 7, - & - & $66 \mathrm{kDa}$ & $\begin{array}{l}\text { (Mohamed-ali et al., } \\
\text { 2014) }\end{array}$ \\
\hline Pleurotus ostreatus & $\mathrm{SmF}$ & $25^{\circ} \mathrm{c}$ & $\begin{array}{l}\text { Glucose, KH2PO4, } \\
\text { MgSO4, Soy milk. }\end{array}$ & 6 & Fibrin plate & 5,2 & $\mathrm{pH} 7,4,45^{\circ} \mathrm{C}$ & EDTA & $18,2 \mathrm{kDa}$ & (Liu et al., 2014) \\
\hline $\begin{array}{l}\text { Lyophyllum } \\
\text { shimeji }\end{array}$ & - & - & - & - & Fibrin plate & 5,2 & $\mathrm{pH} 8,37^{\circ} \mathrm{C}$ & PMSF, EDTA & $21 \mathrm{kDa}$ & (Moon et al., 2014) \\
\hline $\begin{array}{l}\text { Rhizopus } \\
\text { microsporus }\end{array}$ & $\mathrm{SmF}$ & $28^{\circ} \mathrm{C}$ & $\begin{array}{l}\text { Solution with soy } \\
(1 \%) \text {, peptone }(1 \%) \\
\text { and dextrin }(2 \%)\end{array}$ & 2,5 & Fibrin plate & 43,2 & $\mathrm{pH} 7,37^{\circ} \mathrm{C}$ & - & $24,5 \mathrm{kDa}$ & (Zhang et al., 2015) \\
\hline $\begin{array}{l}\text { Cordyceps } \\
\text { militaris }\end{array}$ & $\mathrm{SmF}$ & $23^{\circ} \mathrm{C}$ & $\begin{array}{l}\text { Soy }(5 \%) \text { and } \\
\text { Sucrose }(2 \%)\end{array}$ & 5 & Fibrin plate & 40,7 & $\mathrm{pH} 7,4,37^{\circ} \mathrm{C}$ & PMSF & $32 \mathrm{kDa}$ & (Liu et al., 2015) \\
\hline $\begin{array}{l}\text { Neurospora } \\
\text { sitophila }\end{array}$ & SSF & $28^{\circ} \mathrm{C}$ & $\begin{array}{l}\text { Soybeans and } \\
\text { Wheat Bran }\end{array}$ & 2 & Fibrin plate & 9,2 & $\mathrm{pH} 7,6,41^{\circ} \mathrm{C}$ & $\begin{array}{l}\text { PMSF, Aprotinin, } \\
\text { SBTI }\end{array}$ & - & (Liu et al., 2016) \\
\hline Xylaria curta & SSF & $28^{\circ} \mathrm{C}$ & Rice bran & 15 & Fibrin plate & 1,1 & $\mathrm{pH} 8,35^{\circ} \mathrm{C}$ & EDTA, EGTA & $33 \mathrm{kDa}$ & (Meshram et al., 2016) \\
\hline $\begin{array}{c}\text { Mucor } \\
\text { subtilissimus }\end{array}$ & SSF & $25^{\circ} \mathrm{c}$ & Wheat bran & 3 & Spectrophotometry & 57,1 &,$- 37^{\circ} \mathrm{C}$ & PMSF & - & $\begin{array}{l}\text { (Nascimento et al., } \\
\text { 2016) }\end{array}$ \\
\hline Xylaria curta & $\mathrm{SmF}$ & $28^{\circ} \mathrm{C}$ & Czapek Dox & 7 & Fibrin plate & 3,99 & $\mathrm{pH} 8,35^{\circ} \mathrm{C}$ & EDTA, EGTA & $33 \mathrm{kDa}$ & (Meshram et al., 2016) \\
\hline $\begin{array}{l}\text { Cordyceps } \\
\text { militaris }\end{array}$ & SmF & $23^{\circ} \mathrm{C}$ & $\begin{array}{l}\text { Soy }(5 \%) \text { and } \\
\text { Sucrose }(2 \%)\end{array}$ & 5 & Fibrin plate & 40,7 & $\mathrm{pH} 7,2,37^{\circ} \mathrm{C}$ & SBTI & $28 \mathrm{kDa}$ & (Liu et al., 2017) \\
\hline
\end{tabular}


Research, Society and Development, v. 11, n. 2, e13611225449, 2022

(CC BY 4.0) | ISSN 2525-3409 | DOI: http://dx.doi.org/10.33448/rsd-v11i2.25449

\begin{tabular}{|c|c|c|c|c|c|c|c|c|c|c|}
\hline $\begin{array}{c}\text { Mucor } \\
\text { subtilissimus }\end{array}$ & SSF & $25^{\circ} \mathrm{c}$ & Wheat bran & 3 & Spectrophotometry & 2,54 & $\mathrm{pH} 8,40^{\circ} \mathrm{C}$ & PMSF & $20 \mathrm{kDa}$ & $\begin{array}{l}\text { (Nascimento et al., } \\
\text { 2017) }\end{array}$ \\
\hline Pleurotus ferulae & - & - & - & - & Fibrin zymography & 21,01 & $\begin{array}{c}\mathrm{pH} 4,5 \text { e } 8 \\
50^{\circ} \mathrm{C}\end{array}$ & EDTA, EGTA & $20 \mathrm{kDa}$ & (Choi et al., 2017) \\
\hline $\begin{array}{l}\text { Neurospora } \\
\text { sitophila }\end{array}$ & SSF & $28^{\circ} \mathrm{C}$ & $\begin{array}{c}\text { Soybean residue and } \\
\text { Wheat bran }\end{array}$ & 2 & And fibrin plaque & 9,2 & $\mathrm{pH} 7,4,50^{\circ} \mathrm{C}$ & $\begin{array}{l}\text { PMSF, SBTI, } \\
\text { TPCK }\end{array}$ & $49 \mathrm{kDa}$ & (Deng et al., 2018) \\
\hline $\begin{array}{c}\text { Mucor } \\
\text { subtilissimus }\end{array}$ & $\mathrm{SmF}$ & $30^{\circ} \mathrm{C}$ & $\begin{array}{l}\text { Wheat or soy bran } \\
\text { (MS-2) }\end{array}$ & 4 & Fibrin plate & 4,83 & $\mathrm{PH} 7,50^{\circ} \mathrm{C}$ & $\begin{array}{c}\text { PMSF, } \beta- \\
\text { mercaptoethanol, } \\
\text { EDTA }\end{array}$ & $52 \mathrm{kDa}$ & $\begin{array}{c}\text { (Clementino et al., } \\
\text { 2019) }\end{array}$ \\
\hline $\begin{array}{c}\text { Mucor } \\
\text { subtilissimus }\end{array}$ & SSF & $25^{\circ} \mathrm{c}$ & Wheat bran & 3 & Spectrophotometry & 26,1 & $\mathrm{pH} 9,40^{\circ} \mathrm{C}$ & - & $70 \mathrm{kDa}$ & $\begin{array}{l}\text { (Nascimento et al., } \\
\text { 2020) }\end{array}$ \\
\hline Agrocybe aegerita & - & - & - & - & Spectrophotometry & 7,24 & $\mathrm{PH} 7,6,47^{\circ} \mathrm{C}$ & PMSF, SBTI & $31,4 \mathrm{kDa}$ & (Li et al., 2021) \\
\hline
\end{tabular}

*SmF: Submerged Fermentation. SSF: Solid State Fermentation. Source: Authors (2022). 
Regarding the score, none of the selected articles reached the maximum score, as can be seen in Table 3. Most articles ( $85 \%$ of the selected articles) scored between 6 and 8 (38\%, 28\% and 19\%, respectively), however only $52.4 \%$ scored above 7, only one article reached a score of 9, Meshram et al. (2016) evaluated the production of fibrinolytic enzyme by Xylaria curta under solid state fermentation, obtaining specific activity of up to $9.22 \mathrm{U} / \mathrm{mg}$, the authors were able to perform and publish in a single work the production conditions, with evaluation of different agro-waste as substrate, enzymatic characterization, purification by chromatographic techniques and application. Among the criteria evaluated, the presence of some application activity of the studied enzyme was the least scored (only $38.1 \%$ of the articles), revealing the deficiency in more in-depth studies on the enzymes produced, providing guidance for the enzymes produced.

Table 3. Score of selected articles.

\begin{tabular}{ccccccc}
\hline REFERENCE & A & B & C & D & E & TOTAL \\
\hline (KIM et al., 2011) & 0 & 2 & 1 & 2 & 0 & 5 \\
(CHOI et al., 2011) & 0 & 2 & 1 & 2 & 0 & 5 \\
(KUMARAN et al., 2011) & 1 & 1 & 1 & 2 & 1 & 7 \\
(SHIRASAKA et al., 2012) & 1 & 2 & 1 & 2 & 0 & 6 \\
(CHOI et al., 2013) & 1 & 2 & 2 & 2 & 0 & 7 \\
(MOHAMED ALI et al., 2014) & 1 & 0 & 2 & 1 & 0 & 4 \\
(LIU et al., 2014) & 1 & 2 & 1 & 2 & 0 & 6 \\
(MOON et al., 2014) & 1 & 2 & 1 & 2 & 0 & 6 \\
(ZHANG et al., 2015) & 1 & 2 & 1 & 2 & 0 & 6 \\
(LIU et al., 2015) & 1 & 2 & 1 & 2 & 1 & 8 \\
(LIU et al., 2016) & 1 & 2 & 1 & 2 & 1 & 8 \\
(MESHRAM et al., 2016) & 2 & 2 & 1 & 2 & 1 & 9 \\
(NASCIMENTO et al., 2016) & 1 & 2 & 2 & 1 & 0 & 5 \\
(MESHRAM et al., 2016) & 1 & 2 & 1 & 2 & 1 & 8 \\
(LIU et al., 2017) & 1 & 2 & 1 & 2 & 0 & 6 \\
(NASCIMENTO et al., 2017) & 1 & 2 & 2 & 2 & 0 & 7 \\
(CHOI et al., 2017) & 1 & 1 & 1 & 2 & 1 & 7 \\
(DENG et al., 2018) & 1 & 2 & 1 & 2 & 0 & 6 \\
(CLEMENTINO et al., 2019) & 2 & 2 & 2 & 1 & 0 & 7 \\
(NASCIMENTO et al., 2020) & 1 & 1 & 2 & 2 & 1 & 8 \\
(LI et al., 2021) & 0 & 2 & 1 & 2 & 1 & 7 \\
\hline
\end{tabular}

*(A): Production: with variables (2), without variables (1), absent (0);

(B): Characterization: total (2), partial (1) and absent (0);

(C): Fibrinolytic Activity: Fibrin plate (1) or spectrometer (2);

(D): Purification: total (2), partial (1) or absent (0);

(E): Applications: present (2) or absent (0).

Source: Authors (2022)

\subsection{Fungus}

Twelve different genera were observed in the fungi used in the selected articles, (Paecilomyces, Agrocybe, Aspergillus, Rhizopus, Cordyceps, Pleurotus, Mucor, Xylaria, Ganoderma, Neurospora, Hericium, Auricularia, Lyophyllum), among these, most articles used fungi of the Ascomycota or Basidiomycota phylum, they make up more than 98\% of terrestrial fungi, with the Ascomycota phylum being considerably richer in number of species (Wang et al., 2010). The phylum Zygomicota, considered in flux, was present in 5 articles, of which 4 were represented by the genus Mucor. These fungi are characterized by rapid growth and abundant spore production (Zabell \& Morell, 2020).

Filamentous fungi are known as excellent enzyme producers, being known mainly for the high recovery of proteases (Souza et al., 2015). 8 articles among those analyzed (38.1\%) used some kind of filamentous fungus, indicating that although 
there is a tendency to use these microorganisms, they can still be further explored, especially taking into account biological diversity and the possibility of genetic alteration. Other reported advantages about its application take into account logistical and financial issues, since the production of protease by filamentous fungi benefits from its extracellular secretion, facilitating extraction and purification since there is no need for cell lysis, reducing steps in the process of obtaining these biomolecules (Batista et al., 2020; Martinez-Medina et al., 2019). The use of cell disruption, in addition to adding more steps to the process, also makes it more complete, since the lysis fragments characterize a greater number and diversity of contaminating molecules and an increase in the viscosity of the medium. In addition to requiring a greater number of operations during purification, consequently making the final cost higher than those of extracellular products (Pessoa-JR, 2020).

Although filamentous fungi are gaining ground in the production of enzymes, obtaining fibrinolytic proteases from mushrooms is significantly higher (61.9\%), with several authors highlighting their efficiency and safety, especially in the use of edible mushrooms, studied by presence of natural bioactives and used in folk medicine as herbal medicine. Currently, several mushroom extracts with antioxidant, antitumor, immunomodulatory, antifungal, hypotensive and anticoagulant activities are available in the literature (Kim et al., 2011; Li et al., 2021). It is noteworthy that the use of fungi in general has advantages related to fermentation under various environmental conditions, such as $\mathrm{pH}$, temperature, light, and the variety of substrates that can be used as nutrients (Haq et al., 2004).

\subsection{Cultivation Conditions}

The production of fibrinolytic protease is extremely influenced by the composition of the fermentation medium, especially carbon and nitrogen sources and physical factors such as temperature, $\mathrm{pH}$, agitation, inoculum concentration and fermentation time. Each organism is able to reach the maximum enzyme production in a specific condition, therefore, the optimization of the medium components and the culture parameters is essential in the biological process. This review analyzed 21 studies, of which only 2 evaluated different conditions during fermentation. Meshran et al. (2016) evaluate the effect of several sources of nitrogen and carbon as substrate, such as: rice bran, wheat bran, eggshell, orange peel and banana peel. No analysis regarding physical factors was performed. In contrast, Clementino et al. (2019) used the extractive fermentation technique to obtain pre-purified enzyme in a single step, varying not only the culture medium (wheat bran and soybean bran) but also the composition and concentration of the aqueous two-phase system applied to $2^{3}$ factorial planning. The optimization of the composition of the medium and the physical conditions are applied to increase the production of enzymes and it is an important parameter in the development of an economically viable process.

One of the main factors that must be taken into account in the production of proteases is the type of fermentation adopted. Currently, the most used technique is Submerged Fermentation (FS), with lower viscosity and possibility of agitation and aeration (Castro et al., 2011). In contrast, Solid State Fermentation (FES) reduces the likelihood of bacterial contamination and results in a more concentrated extract. The main difference between the two fermentation models is the amount of free water present (Santos et al., 2018). Among the articles analyzed that used fungi of the phylum Basidiomycota as producers, five did not report fermentation parameters, two used FS and none FES. As for the fungi of the phylum Ascomycota, six used FES, six used FS and two did not propose fermentation parameters. FES has been increasingly used in the production of fungi as it simulates its natural environment, favoring growth (Soccol et al., 2017), in addition to meeting the industrial demand for the use of ecological and economic resources, as it enables the application of agro-industrial residues. Still on the use of FES, the use of substrates such as wheat, soybean and rice bran was observed among the selected works, the former being present in $83 \%$ of fermentations alone or in some type of composition.

The physical parameters described in the analyzed studies can be seen in Table 1. The temperature conditions varied between $23^{\circ} \mathrm{C}$ and $30^{\circ} \mathrm{C}$. These conditions are advantageous for use in industry, considering that the temperatures used are easily 
reached, facilitating maintenance during this important step (Mamo et al., 2020). Another important factor during fermentation is the $\mathrm{pH}$ of the medium, however only one paper presents this information, Xiao-Ian et al. (2014) used a synthetic medium (soy milk, glucose, $\mathrm{KH}_{2} \mathrm{PO}_{4}$ and $\mathrm{MgSO}_{4}$ ) with $\mathrm{pH} 7$ in $\mathrm{FS}$ at $25^{\circ} \mathrm{C}$, more information can be seen in table 2. The lack of information regarding such important parameters affects the quality of the research, hindering the reproduction and introduction of fungi with great biotechnological potential in the industry.

\subsection{Fibrinolytic Activity}

The presence of proteases with fibrinolytic action can be verified in the laboratory using different methodologies. The Fibrin Plate Lysis Area (ALPF) test is considered a direct measure of fibrinolytic activity (Flute and MCPath, 1964), this methodology allows the confirmation of the presence of fibrinolytic enzymes from the formation of a degradation halo. More modern methodologies use spectrophotometry to quantify fibrinolytic proteases. In this case, the enzyme is applied in a tube containing an artificially produced clot, the reaction occurs for a predetermined time, at the end, the clot dissolution can be noticed (Wang et al., 2011), the reaction must be stopped and the reading performed in a spectrophotometer.

Regarding fibrinolytic enzyme quantification methodologies, most of the selected articles (71.42\%) used ALPF, more specifically, the methodology described by Astrup and Mullertz (1952). Zhang et al. (2015) showed the highest specific activity using ALPF to measure the fibrinolytic activity produced by Rhizopus microsporus (43.2 U/mg) in FS. Cordyceps militaris, also produced under FS, had a similar activity of $40.7 \mathrm{U} / \mathrm{mg}$ (Liu et al., 2015; Liu et al., 2016) Of the 5 studies (23.8\%) that used spectrophotometric methodology, 4 were performed with the fungus Mucor subtilissimus, which was capable of producing up to $57.1 \mathrm{U} / \mathrm{mg}$ of fibrinolytic enzyme in FES (Nascimento et al., 2020). The use of spectrophotometric techniques implies a more assertive quantification of the biomolecule of interest since it is a sensitive and automated technique (Galo and Colombo, 2009).

\subsection{Purification}

Fibrinolytic enzymes are applied in the pharmaceutical industry, this approach implies the need to achieve a high degree of purity, so it is common to use more than one chromatography in sequence, such as gel filtration, ion exchange, hydrophobic interaction or affinity. Other techniques can still precede the purification process such as salt precipitation or by organic solvents, centrifugation and filtration. These strategies are commonly referred to as pre-purification steps, signaling the process of preparation for purification itself (Guggisberg et al., 2011).

Purification of the enzymes studied in the analyzed articles was classified, according to the proposed methodology, in total (score 2), showing the enzyme purified by more than one chromatographic step; Partial (score 1), showing the enzyme purified in pre-purification, chromatographic or aqueous two-phase system (SDFA) methodologies; or absent (score 0, when no purification methodology is reported. As can be seen in Table 3, of the 21 selected articles, 18 (85.7\%) presented fibrinolytic activity of purified enzymes, and none of the articles received a score 0 .

Using ALPF to determine the fibrinolytic activity of an enzyme produced by Paecilomyces tenuipes, Kim et al. (2011). obtained specific activity of $431.81 \mathrm{U} / \mathrm{mg}$ and recovery of $3.8 \%$ after consecutive steps of CM cellulose, DEAE-sepharose CL6B fast flow, Sephadex G-75 and POROS 20 HQ. The combination of different types of chromatographic columns supports the individualization of the molecule of interest. The same can be seen in the purification of enzyme produced by Aspergillus oryzae KSK-3, which used steps followed by precipitation with ammonium sulfate, ultrafiltration and chromatography (DEAEToyopearl 650C, Sephacryl S-100HR and Superdex 75 HR 10/30), resulting in specific activity of 1005 U/mg). Already using spectrophotometry to quantify the proteases produced, Choi et al. (2013) used the sequence of CM cellulose, DEAE cellulose, Sephadex G-75, HiLoad 16/60 and Superdex 75 to obtain 220.65 U/mg of fibrinolytic enzyme produced by Hericium erinaceum. 
While Nascimento et al. (2017) presents $154.79 \mathrm{U} / \mathrm{mg}$ after precipitation in ammonium sulfate, DEAE-Sephadex and Superdex 75 HR10/300 GL.

\subsection{Enzymatic characterization}

Enzymatic characterization is carried out using processes that involve chemical or physical agents. These agents are capable of affecting the native state of the enzyme and may even lead to denaturation and consequent total loss of activity. Thus, the characterization of produced enzymes, especially when destined for the pharmaceutical industry, is essential.

\subsubsection{Optimal pH and Temperature}

The optimal $\mathrm{pH}$ of the enzymes, that is, the $\mathrm{pH}$ range where they showed the greatest fibrinolytic activity, varied between pH 4 and 9, demonstrating a wide range of enzymes capable of maintaining themselves in acidic or alkaline conditions. However, most of the studied enzymes showed optimal pH in the range 7 (38\%) and 8 (19\%). Choi et al. (2017) showed optimal activity of enzyme produced by Pleurotus ferulae in three distinct $\mathrm{pH}$ ranges $(4,5$ and 8$)$, being the only work to report activity at $\mathrm{pH} 4$,

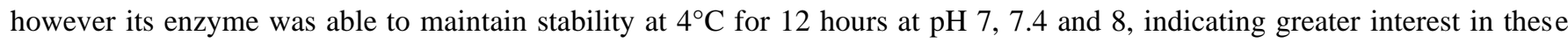
conditions. At the other extreme, only one work showed optimal activity of enzymes produced by Mucor subtilissimus at pH 9 (with 23.3 U/mL) (Nascimento et al., 2020). Only two studies did not assess optimal pH or stability, Nascimento et al. (2016) presents only data regarding the optimal temperature, however the same authors assess these conditions in another publication (Nascimento et al., 2020). And Kumaram et al. (2011) does not report an assessment of these parameters.

Regarding the optimal temperature, as shown in Table 2, they vary between $35^{\circ} \mathrm{C}$ and $50^{\circ} \mathrm{C}$, comprising $23.9 \%$ of the articles with more pronounced fibrinolytic activity at $37^{\circ} \mathrm{C}$ (Moon et al., 2014; Zhang et al., 20158; Liu et al., 2015; Choi et al., 2017; Liu et al., 2017) and 19\% with maximum activity at $50^{\circ} \mathrm{C}$ (Shirasaka et al., 2012; Deng et al., 2018; Clementino et al., 2019). Two works did not present information regarding this data (Kumaram et al., 2011; Mohamed-Ali et al., 2014). Information regarding the optimum $\mathrm{pH}$ and temperature are extremely important for the development of basic and application research, establishing the ground for the development of valid alternatives for the treatment of thrombosis, so it is extremely important that in works where production and characterization of fibrinolytic enzymes, parameters with optimal $\mathrm{pH}$ and temperature, as well as stability, are determined.

\subsubsection{Inhibitors}

Inhibition of fibrinolytic proteases is another relevant segment of the characterization; inhibitors can act on enzymes by modifying structural characteristics that determine their mechanism of action and consequently inhibit enzymatic activity (Vargas, 2020). According to the studies analyzed, several compounds were able to inhibit the activity of the enzymes studied, these were PMSF (serine protease inhibitor) (Kim et al., 2011; Choi et al., 2011; Liu et al., 2017; Moon et al., 2014; Liu et al., 2015; Liu et al., 2016; Nascimento et al., 2016; Nascimento et al., 2017; Shirasaka et al., 2012; Cleentino et al., 2011); EDTA (metalloprotease inhibitor) (Guggisberg et al., 2011; Xiao-Ian et al., 2014; Meshram et al., 2016; Andrade et al., 2018; Meshram et al., 2016; Lins et al., 2019); SBTI (serine protease inhibitor) (Liu et al., 2016; Liu et al., 2017; Deng et al., 2018; Li et al., 2020); Aprotinin (Inhibitor of serine and cysteine protease) (Liu et al., 2016); TPCK (serine protease inhibitor) (Shirasaka et al., 2021); EGTA (metalloprotease inhibitor) (Choi et al., 2013; Meschram et al., 2016; Andrade et al., 2018; Meshram et al., 2016; Lins et al., 2019; Choi et al., 2016) and $\beta$-mercaptoethanol (cysteine protease inhibitor) (Clementino et al., 2019).

Of the 21 articles selected, only four did not conduct tests evaluating the inhibition of enzymatic activity, according to these data, $81 \%$ of the analyzed articles identified fibrinolytic enzymes as serine proteases and $19 \%$ presented data demonstrating the presence of metalloprotease. 


\subsubsection{Molecular mass}

The molecular mass of the enzymes studied in the selected works varies between $14 \mathrm{kDa}$ and $70 \mathrm{kDa}$, however, more than half of the works (52.4\%) present enzymes between 20 and $34 \mathrm{kDa}$. At the extremes of the spectrum we have Kim et al., (2011) presenting fibrinolytic enzyme (1431.81 U/mg) produced by Paecilomyces tenuipes with $14 \mathrm{kDa}$ in size; and Nascimento et al., (2020) presenting fibrinolytic enzyme (43.12 U/mg) produced by Mucor subtilissimus with $70 \mathrm{kDa}$. Three articles did not present data.

\section{Final Considerations}

Excessive search was performed in databases reporting a total of 426 articles in general, after applying predetermined inclusion and exclusion criteria, 21 articles published between 2011 and 2021 were selected. According to the analysis and scoring criteria, it was observed that $52.4 \%$ of the articles had a final score above 7 , however only one reached a score 9 presenting information on obtaining the enzyme from the evaluation of the cultivation conditions to the application of the enzyme, and none reached the maximum score (10). Thus, it is important to direct more in-depth research on fibrinolytic enzymes produced by fungi, considering that such molecules show great variation. It is noteworthy that, despite being quite promising, solid state fermentation is still not sufficiently explored, especially in relation to studies with substrate analysis or factorial planning, being present in only two of the analyzed works. Almost all articles presented complete purification and characterization, indicating $\mathrm{pH} 7-8$ and $37^{\circ} \mathrm{C}$ as optimal conditions for enzyme activity, in addition to highlighting a higher prevalence of serine proteases in the analyzed studies.

The analysis performed was also able to verify the tendency of the prevalence of purification and characterization of enzymes on the production and application in the analyzed works. However, the optimization of cultivation and production parameters can be decisive for the frequency of fibrinolytic activity. Similarly, studies involving the application of the enzyme can also be deterministic in its industrial direction, an essential quality for its future fate as a thrombolytic agent. In this way, this work indicates the need to expand the publications related to the production of fibrinolytic enzymes as well as the evaluation of their applications. As for purification and characterization, despite being more present in the studies studied, as they are such important parts in the development and application of this enzyme, it is necessary to pay attention to the development of a more complex characterization, exploring the physicochemical properties of the enzyme.

\section{Acknowledgments}

The authors acknowledge the financial support from CAPES (Coordenação de Aperfeiçoamento de Pessoal de Nível Superior, Brasilia, Brasil) (no 88887.175810/2018-00) (CAPES/FACEPE - 18/2016); CAPES PRINT (nº 88887.568973/202000), FACEPE (Fundação de Amparo à Ciência e Tecnologia do Estado de Pernambuco, Recife, Brasil) (BFP-0079-5.05/20) and CNPq (Conselho Nacional de Desenvolvimento Científico e Tecnológico, Brasilia, Brasil) and Clariant Brasil for the dyes supplied.

\section{Conflict of interests}

The authors declare no conflict of interest.

\section{References}

Ali, A. M. M. \& Bavisetty, S. C. B. (2020). Purification, physicochemical properties, and statistical optimization of fibrinolytic enzymes especially from fermented foods: A comprehensive review. International Journal of Biological Macromolecules, 163 (15), $1498-1517$. 
Andrade, M. V. S. Andrade, L. A. P., Bispo, A. F. P., Freitas, L. A., Andrade, M. Q. S., Feitosa, G. S., \& Feitosa-Filho, G. S. (2018). Evaluation of the bleeding intensity of patients anticoagulated with warfarin or dabigatran undergoing dental procedures. Arquivo Brasileiro de Cardiologia, 111 (3), $394-399$.

Astrup, T. \& Mullertz, S. (1952). The fibrin plate method for estimating fibrinolytic activity. Archives of Biochemistry and Biophysics, 40 (2), $346-351$.

Batista, J. M. S. Neves, A. G. D., Ferreira, J. V. S., Cunha, M. N. C., Costa, R. M. P. B., \& Porto, A. L. F. (2021). Purification and biochemical characterization of an extracellu lar fructosyltransferase - rich extract produced by Aspergillus tamarii Kita UCP1279. Biocatalysis and Agricultural Biotechnology,26 (1), 1-9.

Bin, W., Licheng W., Daijie C., Zhijun Y., \& Minyu L. (2009). Purification and characterization of a novel fibrinolytic protease from Fusarium sp. CPCC 480097. Journal of Industrial Microbiology and Biotechnology, 36 (3), 451-459.

Castro, A. M., Teixeira, M. M. P., Carvalho, D. F., Freire, D. M. G. \& Castilho, R. (2011). Multiresponse Optimization of Inoculum Conditions for the Production of Amylases and Proteases by Aspergillus awamori in Solid-State Fermentation of Babassu Cake. Enzyme Research, 2011 (1), 1-10.

Chen, Y., Fu, X., Mei, X., \& Zhou, Y. (2016). Characterization of functional proteases from flowers of tea (Camellia sinensis) plants. Journal of Functional Foods, 25, 149-159.

Choi, B., Sapkota, K. Choi, J., Shin, C., Kim, S., \& Kim, S. (2013). Herinase: A Novel Bi-functional Fibrinolytic Protease from the Monkey Head Mushroom, Hericium erinaceum. Applied Biochemistry and Biotechnology, 170, 609-622.

Choi, D., Cha, W., Park, N., Kim, H., Lee, J. H., Park, J., \& Park, S. (2011). Purification and characterization of a novel fibrinolytic enzyme from fruiting bodies of Korean Cordyceps militaris. Bioresource Technology, 102, 3279-3285.

Choi, J., Kim, D., Kim, S., \& Kim, S. (2017). Purification and partial characterization of a fibrinolytic enzyme from the fruiting body of the Medicinal and edible mushroom Pleurotus ferulae. Preparative Biochemistry \& Biotechnology, 47 (6), 539-546.

Clementino, EL. L., Sales, A. E., Cunha, M. N. C., Porto, A. L. F., \& Porto, T. S. (2019). Produção e purificação integrada de protease fibrinolítica de Mucor subtilissimus UCP 1262. Arquivo Brasileiro de Medicina Veterinária e Zootecnia, 71, 553-562.

Deng, Y., Liu, X., Katrolia, P., Kopparapu, N. K., \& Zheng, X. (2018). A dual-function chymotrypsin-like serine protease with plasminogen activation and fibrinolytic activities from the GRAS fungus, Neurospora sitophila. International Journal of Biological Macromolecules, 109, $1338-1343$.

Flute, P. T. \& MCPath, M. D. (1964). Hamorrhage and Fibrinolysis. 57 (7), 603-606.

Galo, L. A., \& Colombo, M. F. (2009). Espectrofotometria de longo caminho óptico em espectrofotômetro de duplo-feixe convencional: uma alternativa simples para investigações de amostras com densidade óptica muito baixa. Quimica. Nova, 32 (2), 488-492.

Greenhalgh T. (1997). How to read a paper. Papers that summarise other papers (systematic reviews and meta-analyses). BMJ. 315, 668-671.

Guggisberg, D., Risse, G. M. C., \& Hadorn, H. (2011). Determination of Vitamin B-12 in meat products by RP-HPLC after enrichment and purification on an immunoaffinity column. Meat Science, 90, 279-283.

Haq, I. (2004). Protease biosynthesis by mutant strain of Penicillium griseoroseum and cheese formation. Pakistan Journal of Biological Sciences, 7, $1473-1476$.

Kim, H, C., Choi, B. S., Sapkota, K. Kim, S. Lee, H. J., Yoo, J. C., \& Kim, J. (2011). Purification and characterization of a novel, highly potent fibrinolytic enzyme from Paecilomyces tenuipes. Process Biochemistry, 45, 1545-1553.

Kumaran, S., Palani, P., Nishanthi, R., \& Kaviyarasan, V. (2011). Studies on Screening, Isolation and Purification of a Fibrinolytic Protease from an Isolate (VK12) of Ganoderma lucidum and Evaluation of its Antithrombotic Activity. Medical Mycology Journal, 52, $153-162$.

Li, G., Liu, X., Cong, S., Deng, Y. \& Zheng, X. (2021). A novel serine protease with anticoagulant and fibrinolytic activities rom the fruiting bodies of mushroom Agrocybe aegerita. International Journal of Biological Macromolecules, 168, 631-639.

Lins, S., Wang, Y., Zhang L., \& Guan, W. (2019). Dabigatranmust be used carefully: literature review and recommendations for management of adverse events Drug design, development and therapy, 13, 1527-1533.

Liu, X., Kopparapu, N., Li, Y., Deng, Y., \& Zheng, X. (2017). Biochemical characterization of a novel fibrinolytic enzyme from Cordyceps militaris. International Journal of Biological Macromolecules, 94, 793-801.

Liu, X., Kopparapu, N. K., Shi, X., Deng, Y. P., Zheng, X., \& Jianping W. (2015). Purification and biochemical characterization of a novel fibrinolytic enzyme from culture supernatant of Cordyceps militaris Journal of Agricultural and Food Chemistry, 63 (8), 2215-2224.

Liu, X., Kopparapu, N. K., Shi, X., Deng, Y. P., Zheng, X., Katrolia P. \& Xheng, H. (2016). Purification and characterization of a fibrinolytic enzyme from the food-grade fungus, Neurospora sitophila.. Journal of Molecular Catalysis B: Enzymatic, 134, 98-104.

Liu, X., Zheng, X., Qian, P., Kopparapu, N., Deng, Y., Nonaka, M., \& Harada, N. (2014). Purification and Characterization of a Novel Fibrinolytic Enzyme from Culture Supernatant of Pleurotus ostreatus. Journal of Microbiology and Biotechnology, 24 (2), $245-253$.

Mamo, J., Kangwa, M., Fernandez-Lahore, H. M., \& Assefa, F. (2020). Optimization of media composition and growth conditions for production of milkclotting protease (MCP) from Aspergillus oryzae DRDFS13 under solid-state fermentation. Brazilian Journal of Microbiology, 51, 571-584.

Martínez-Medina, G. A., Barragán, A. P., Ruiz, H. A. Ilyina, A., Hernández, J. L. M., Rodríguez-Jasso, R. M., Concha, j. 1., \& Aguilar-González, C. N. (2019). Fungal Proteases and Production of Bioactive Peptides for the Food Industry. Enzymes in Food Biotechnology, 14, $221-245$.

Meshram, V., Sanjai S., Mahiti G., \& Neha, K. (2016). Production, Purification and Characterisation of a Potential Fibrinolytic Protease from Endophytic Xylaria curta by Solid Substrate Fermentation. Applied Biochemistry and Biotechnology, 181 (4), 1496-1512. 
Meshram, V., Saxena, S., \& Paul, K. (2016). Xylarinase: a novel clot busting enzyme from an endophytic fungus Xylaria curta. Journal of Enzyme Inhibition and Medicinal Chemistry, 31 (6), 1502-1511.

Mohamed Ali, S., Ling, T. C., Muniand, S., Raman, S. T. J., \& Sabaratnam. V. (2014). Recovery and partial purification of fibrinolytic enzymes of Auricularia polytricha (Mont.) Sacc by an aqueous two-phase system. Separation and Purification Technology, 122, 359-366.

Moon, S., Kim, J., Kim, H., Choi, M., Park, B. R., Kim, G., Ahn, H., Chun, H. S., Shin, Y. K., Kim, J., Kim, D., K., Lee, S., Seo, W., Kim, Y. H., \& Kim, C. S (2014). Purification and characterization of a novel fibrinolytic a chymotrypsin like serine metalloprotease from the edible mushroom, Lyophyllum shimeji. Journal of Bioscience and Bioengineering, 117 (5), 544-550.

Nascimento, T. P., Coniff, A. E. S. Moura, J. A. S., Batista, J. M. S., Bosta, R. M. P. B., Posto, C. S., Takaki, G. M. C., Porto, T. S., \& Posto, A. L. F. (2020). Protease from Mucor subtilissimus UCP 1262: Evaluation of several specific protease activities and purification of a fibrinolytic enzyme. Anais da Academia Brasileira de Ciencias, 92 (4), 1-12.

Nascimento, T. P., Salles, A. E. Porto, T. S., Costa, R. M. P B., Breudo, Uversky, V. N., Porto, A. L. F., \& Converti, A. (2017). Purification, biochemical, and structural characterization of a novel fibrinolytic enzyme from Mucor subitillissimus UCP 1262. Bioprocess Biosystem Engineering, 40, $1209-1219$.

Nascimento, T. P., Salles, A. E. Porto, T. S., Costa, R. M. P B., Breudo, Uversky, V. N., Porto, A. L. F., \& Converti, A. (2016). Purification of a fibrinolytic protease from Mucor subtilissimus UCP 1262 by aqueous two-phase systems (PEG/sulfate). Journal of Chromatography B, 1025, 16-24.

Pessoa-Jr, A. 2020. Rompimento celular. In. Kilikian, B. V., \& Pessoa-Jr, A. (2020). Purificação de produtos biotecnológicos: operações e processos com aplicação industrial. $2^{\mathrm{a}}$ ed. São Paulo: Blucher, 67-103.

Raju, E. \& Divakar, G. (2013). Optimization and Production of Fibrinolytic Protease (GD kinase) from Different Agro Industrial Wastes in Solid State Fermentation. Current Trends in Biotechnology and Pharmacy, 7, 763-712.

Santos, P. S., Solidade, L. S., Souza, J. G. B., Sampaio, G. Braga Jr, A. C. R., Assis, F. G. V. \& Leal, P. L. (2018). Fermentação em estado sólido em resíduos agroindustriais para a produção de enzimas: Uma revisão sistemática. The Journal of Engineering and Exact Sciences, 4 (2), 1-8.

Shirasaka, N., Naitou, M., Okamura, K., Kusuda, M., Fukuta, Y., \& Terashita, T. (2012). Purification and characterization of a fibrinolytic protease from Aspergillus oryzae KSK-3. Mycoscience, 53 (5) 354-364.

Soccol, C. R., Costa, E. S. F., Letti, L. A. J., Karp, S, G., Waoicishowski, A. L., \& Vaderberghe, L. P. S. (2017). Recent developments and innovations in solid state fermentation. Biotechnology Research and Innovation, 1, 52-71.

Souza, P. M., Bittencourt, M. L. A., Caprara, C. C., Freitas, M., Almeida, R. P. C., Silveira, D., Fonseca, Y. M. Ferreira-Filho, E. X., Pessoa-Junior, A., \& Magalhães, P. O. (2015). A biotechnology perspective of fungal proteases. Brazilian Journal of Microbioogy,. 46 (2), 1-10.

Wanderley, M. C. A., Neto, J. M. W. D., Filho, J. L. L., Lima, C. A., Teixeira, J. A. C., \& Porto, A. L. F. P. (2017). Collagenolytic enzymes produced by fungi: a systematic review. Brazilian Journal of Microbiology [online], 48 (1), 13-24.

Wang, H., Guo, S., Huang, M., Lumsch, H., \& Thorsten, W. (2010). Ascomycota has a faster evolutionary rate and higher species diversity than Basidiomycota. Science China Life Sciences, 53, 1163-1169.

Wang, S., Wu, Y., \& Liang, T. (2011). Purification and biochemical characterization of a nattokinase by conversion of shrimp shell with Bacillus subtilis TKU007. New Biotechnology, 28 (2), 196-202.

Zabell R. A. \& Morell, J. J. (2020). The characteristics and classification of fungi and bacteria. Wood Microbiology, 55-98.

Zhang, S., Wang, Y., Zhang, N., Sun, Z., Shi, Y., Cao, X., \& Wang, H. (2015). Purification and Characterisation of a Fibrinolytic Enzyme from Rhizopus micro sporus var. Tuberosus. Food Technology and Biotechnology, 53 (2), 243-248. 